\title{
HUBUNGAN ILMU NEGARA DENGAN NEGARA DEMOKRASI
}

\author{
Desmaria Sofiana \\ 1810095600040 \\ SEKOLAH TINGGI ILMU HUKUM
}

\section{A. PENDAHULUAN}

Suatu ilmu pengetahuan tidak dapat dipisahkan dengan ilmu pengetahuan lainnya. Tidak mungkin suatu ilmu pengetahuan berdiri sendiri tanpa berhubungan atau dipengaruhi oleh ilmu pengetahuan lainnya. Ilmu Negara merupakan salah satu cabang dari Ilmu Pengetahuan Sosial seperti halnya Politik, Hukum, Kebudayaan dll. Semua Ilmu Pengetahuan pada akhirnya akan berinduk pada ilmu pengetahuan induk (mater scientarium) yaitu filsafat. Oleh karena itu Ilmu Negara juga tidak dapat berdiri sendiri dan harus bekerja sama dengan ilmu pengetahuan lainnya.

Ilmu Negara sebagai salah satu cabang ilmu pengetahuan harus bekerjasama dengan cabang-cabang ilmu pengetahuan lainnya, terutama ilmu-ilmu kenegaraan sehingga dapat saling mengisi dan melengkapi. Suatu ilmu pengetahuan tidak dapat dipisahkan dengan ilmu pengetahuan lainnya. Tidak mungkin suatu ilmu pengetahuan berdiri sendiri tanpa berhubungan atau dipengaruhi oleh ilmu pengetahuan lainnya. Ilmu Negara merupakan salah satu cabang dari Ilmu Pengetahuan Sosial seperti halnya Politik, Hukum, Kebudayaan dll. Semua Ilmu Pengetahuan pada akhirnya akan berinduk pada ilmu pengetahuan induk (mater scientarium) yaitu filsafat.

Konsep negara hukum merupakan produk dari sejarah, sebab rumusan atau pengertian negara hukum itu terus berkembang mengikuti sejarah perkembangan umat manusia. Karena itu dalam rangka memahami secara tepat dan benar konsep negara hukum, perlu terlebih dahulu diketahui gambaran sejarah perkembangan pemikiran 
politik dan hukum, yang mendorong lahir dan berkembangnya konsepsi negara hukum. Pemikiran tentang Negara Hukum merupakan gagasan modern yang multi-perspektif dan selalu aktual.

Sedangkan Demokrasi bukan hanya metode kekuasaan mayoritas melaui partisipasi rakyat dan kompetisi bebas, tetapi mengandung nilai-nilai universal, khusunya nilai-nilai persamaan, kebebasan dan pluralisme, walaupun konsep operasionalnya berpariasi menurut kondisi dan buadaya negara tertentu, sehingga eksistensi hak asasi manusia. Demokrasi sebagai dasar hidup bernegara memberi pengertian bahwa pada tingkat terakhir rakyat memberikan ketentuan masalah pokok yang mengenai kehidupannya, termasuk dalam menilai kebijaksanaan negara, oleh karena itu kebijaksanaan tersebut menentukan kehidupan rakyat.

Demikian halnya bahwa kedaulatan rakyat adalah asasnya demokrasi dan demokrasi adalah tumpuannya Negara hukum dimana tiap Negara hukum mempunyai landasan tertib hukum dan menjadi dasar keabsahan bertindak. Setiap Negara bersandar pada keyakinan bahwa kekuasaan Negara harus dijalankan atas dasar hukum yang adil dan baik. Esensi pada suatu Negara hukum, pertama: Hubungan antara yang memerintah dan diperintah tidak berdasarkan kekuasaan melainkan berdasarkan suatu norma objektif, yang juga mengikat semua pihak termasuk memerintah; kedua: norma objektif itu harus memenuhi syarat bahwa tidak hanya secara formal, melainkan dapat dipertahankan berhadapan dengan ide hukum. dalam ini nilai-nilai yang tumbuh dan berkembang di masyarakat.

Negara yang menganut Paham demokrasi, maka konsekuensi yang harus lahir dalam konstitusinya pun harus menuangkan atau mencirikan paham demokrasi tersebut. Sebagaimana dijelaskan sebelumnya bahwa pada dasarnya konstitusi merupakan Resultante (Kesepakatan) antara rakyat dengan para penguasa di dalam negara, dengan 
demikian telah jelas bahwa kesepakatan yang dari rakyat kepada pemerintah haruslah memuat aspirasi dari rakyat itu sendiri. Konstitusi dapatlah dikatakan juga sebagai Produk politik, sebab dari kesepakatan antara rakyat dengan pemerintah tersebut, maka dituangkanlah suara kesepakatan itu didalam suatu naskah yang menjadi dasar dan tonggak berdirinya Hukum dalam sebuah Negara.

\section{B. PEMBAHASAN}

\section{Negara Hukum}

Di dalam perpustakaan hukum indonesia istilah negara hukum pada umumnya dianggap dari terjemahan yang tepat dari dua istilah yaitu; rechtstaat dan the role of law. Tetapi rechtstaat dan the role of law mempunyai latar belakang dan pelembagaan yang berbeda. Rechtstaat banyak dianut oleh negara Eropa Kontinental yang bertumpu pada sistem civil law. Sedangkan the role of law banyak dianut oleh eropa Anglo saxon yang bertumpu pada sistem common law.

Konsep negara hukum merupakan produk dari sejarah, sebab rumusan atau pengertian negara hukum itu terus berkembang mengikuti sejarah perkembangan umat manusia. Karena itu dalam rangka memahami secara tepat dan benar konsep negara hukum, perlu terlebih dahulu diketahui gambaran sejarah perkembangan pemikiran politik dan hukum, yang mendorong lahir dan berkembangnya konsepsi negara hukum. Pemikiran tentang Negara Hukum merupakan gagasan modern yang multi-perspektif dan selalu aktual.

Ditinjau dari perspektif historis perkembangan pemikiran filsafat hukum dan kenegaraan gagasan mengenai Negara Hukum sudah berkembang semenjak 1800 Sebelum Masehi. Akar terjauh mengenai perkembangan awal pemikiran Negara Hukum adalah pada masa Yunani kuno. Menurut Jimly Asshiddiqie gagasan bahwa kedaulatan 
rakyat tumbuh dan berkembang dari tradisi Romawi, sedangkan tradisi Yunani kuno menjadi sumber dari gagasan kedaulatan hUkum.

Ilmu Negara merupakan salah satu cabang dari Ilmu Pengetahuan Sosial seperti halnya Politik, Hukum, Kebudayaan dll. Semua Ilmu Pengetahuan pada akhirnya akan berinduk pada ilmu pengetahuan induk (mater scientarium) yaitu filsafat. Oleh karena itu Ilmu Negara juga tidak dapat berdiri sendiri dan harus bekerja sama dengan ilmu pengetahuan lainnya. Selain memiliki hubungan yang bersifat umum dengan ilmu pengetahuan lainnya,

Lahirnya konsep negara hukum yang dikemukakan oleh F.J. Stahl adalah konsep pemikiran negara hukum Eropa Kontinental atau yang dipraktekkan di negara-negara Eropa Kontinental (civil Law). Adapun konsep pemikiran negara hukum yang berkembang di negara-negara Anglo-Saxon yang dipelopori oleh A.V. Decey (dari inggris) dengan prinsip rule of law. Konsep negara hukum tersebut memenuhi 3 (tiga) unsur utama:

a. Supermasi aturan-aturan hukum (Supremacy of the law), yaitu tidak adanya kekuasaan sewenang-wenang (Absence of arbitrary power), dalam arti bahwa seseorang hanya boleh dihukum kalau melanggar hukum ;

b. Kedudukan yang sama dalam menghadapi hukum (Equality before the law), Dalil ini berlaku balk untuk orang biasa maupun untuk pejabat;

c. Terjaminnya hak-hak manusia oleh undang-undang (di Negara lain dengan Undang-Undang Dasar) serta keputusan-keputusan pengadilan.

Unsur-unsur yang terdapat dalam kedua macam negara hukum tersebut di atas, baik Rechtsstaat maupun Rule of Law, mempunyai persamaan dan perbedaan. Persamaan pokok antara Rechtsstaat dengan Rule of Law adalah, adanya keinginan untuk memberikan jaminan terhadap hak-hak asasi manusia. Keinginan memberikan 
perlindungan dan penghormatan terhadap hak asasi itu, telah diimpikan sejak berabadabad lamanya dengan perjuangan dan pengorbanan yang besar

\section{Negara Demokrasi}

Secara teoritis demokrasi adalah suatu pemerintahan dari dari rakyat, oleh rakyat dan untuk rakyat. Jika dikaitkan dengan praktek ketata negaraan meskipun sebuah negara mengklaim dirinya adalah negara demokrasi tetapi dalam banyak hal negara itu sesungguhnya mengabaikan banyak asa-asas dan prinsip demokrasi.101 Dengan demikian secara ekplisit demokrasi meniscayakan pengakuan dan penghargaan pada hakhak rakyat melalui berbagai event seperti melalui pemilihan anggota DRP, pemilihan Presiden, dan wakil Presiden, pemilihan DPD dan DPRD bahkan sampaai pemilihan kepala desa

Demokrasi bukan hanya metode kekuasaan mayoritas melaui partisipasi rakyat dan kompetisi bebas, tetapi mengandung nilai-nilai universal, khusunya nilai-nilai persamaan, kebebasan dan pluralisme, walaupun konsep operasionalnya berpariasi menurut kondisi dan buadaya negara tertentu, sehingga eksistensi hak asasi manusia. Demokrasi sebagai dasar hidup bernegara memberi pengertian bahwa pada tingkat terakhir rakyat memberikan ketentuan masalah pokok yang mengenai kehidupannya, termasuk dalam menilai kebijaksanaan negara, oleh karena itu kebijaksanaan tersebut menentukan kehidupan rakyat.

Berkenaan dengan ciri atau asas terdapat beberapa pendapat atau pandangan, dimana mereka melihatnya atau mengembangkannya dari sudut pandang sejarah, kondisi ataupun konstelasi dimana pakar tersebut melakukan pengamatan atau penelitiannya. Berikut beberapa pendapat terkait negara demokrasi;

a. Sri Sumantri, menyatakan 4 kriteria pembuatan hukum demokratis ; 
- Hukum itu tidak ditetapkan kecuali dengan persetujuan wakil-wakil rakyat yang dipilih secara bebas.

- Hasil pemilihan umum atau campur tangan badan perwakilan rakyat dapat mengakibatkan pergantian orang-orang pemerintahan.

- Pemerintahan harus terbuka.

- Kepentingan minoritas harus dipertimbang atau diakomodasi.

b. Hendri B. Mayo

- Menyelesaikan perselisihan dengan damai dan secara kelembagaan.

- Menjamin terselenggaranya perubahan secara dami dalam suatu masyarakat yang sedang berubah.

- Menyelenggarakan pergantian pemimpin secara teratur.

- Membatasi pemakaian kekerasan secara minimum.

- Mengakui serta menganggap wajar adanya keanekahragaman.

- Menjamin tegaknya keadilan.

c. Mariam Budiarjo, demokrasi konstitusional pertama-tama merupakan rechstaat memperinci 7 demokrasi ciri demokrasi konstitusional yakni;

- Perlindungan konstitusional

- Badan kehakiman yang bebas dan tidak memihak.

- Pemilihan umum yang bebas.

- Kebebasan menyatakan pendapat

- Kebebasan berserikat, berorganisasi dan beroposisi.

- Adanya pendidikan kewarganegaraan (civic education ).

- Kebijakan politik ditetapakan atas kehendak mayoritas.

Tidak dapat disangkal lagi bahwa bebrapa nilai pokok dari demokrasi konstitusional cukup jelas tersirat dalam UUD 1945. Secara ekplisit UUD 1945 
menyebut dua prinsip menjelaskan makna naskah yang dicantumkan dalam pasal 1 ayat (3) mengenai sistem pemerintahn, yaitu:

a. Negara Indonesia adalah negara hukum.

b. Sistem Konstitusionalnya berdasarkan atas sistem konstitusi (hukum dasar) tidak bersifat absolutisme, (kekuasaan yang tidak terbatas).

Berdasarkan dua istilah rechstaat dan "sistem Konstitusi" maka jelaslah bahwa demokrasi yang menjadi dasar dari UUD 1945, ialah demokrasi konstitusional. Disamping itu corak khas demokrasi indonesia yaitu " kerakyatan dipimpin oleh hikmat kebijaksanaan dalam pemusyawaratan perwakilan" yang dimuat dalam pembukaan UUD 1945.

\section{Hubungan Negara Hukum dengan Negara Demokrasi}

Salah satu asas penting negara hukum adalah asas legalitas. Subtansi dari asas legalitas tersebut adalah menghendaki agar setiap tindakan badan/pejabat administrassi berdasarkan Undang-Undang. Tanpa dasar undang-undang, badan/pejabat administrasi negara tidak berwenang melakukan suatu tindakan yang dapat merubah atau mempengaruhi keadaan suatu hukum dalam warga masyarakat. Asas legalitas berkaitan erat dengan gagasan demokrasi dan gagasan negara hukum ( het democrattish ideal en het rechtsstaats ideal).

Gagasan demokrasi menuntut agar setiap bentuk undang-undang dan berbagai keputusan mendapatkan persetujuan dari wakil-wakil rakyat dan sebanyak munkin memperhatikan kepentingan rakyat. Gagasan negara hukum menuntut agar penyelengaraan kenegaraan dan pemerintahan harus didasarkan pada undangundang dan memberikan jaminan terhadap hak-hak dasar rakyat yang tertuang dalam undangundang. 
Menurut Sjachran basah, asas legalitas berarti upaya mewujudkan duet intergral secara harmonis antara anatra paham kedaulatan hukum dengan paham kedaulatan rakyat berdasarkan prinsip monodualistik selaku pilar-pilar, yang sifatnya hakikatnya konstitutif. Penerapan asas legalitas menurut Idroharto, akan menunjang berlakunya kepastian hukum dan berlakunya kesamaan perlakuan.

Secara teoritis dan yuridis sumber asas legalitas asalnya dapat memperoleh badan/pejabat administrasi melalui atributif (legislator), baik ditingkat pusat maupun ditingkat daerah. Di indonesia, asas legalitas berupa atributif tersebut pada tingkat pusat sumbernya dapat diperoleh (berasal dari MPR melalui UUD dan dari DPR bersama-sama Presiden berupa Undang-Undang sedangkan atributif yang asalnya diperoleh dari pemerintahan tingkat daerah yang sumbernya dari DPRD dan Pemerintah daerah adalah peraturan daerah. Kedua asal wewenang tersebut diatas original legislator atau berasal dari pembuat undang-undang asli (originale wetgever).

Atas dasar hal itulah kemudian menjadi penyerahan suatu wewenang baru dari pembentuk undangundang (rakyat melalui wakil-wakilnya di parlemen) kepada badan/pejabat administrasi Indonesia. Selanjutnya atas dasar atributif itu tindakan badan/pejabat administrasi Indonesia menjadi sah secara yuridis dan mempunyai kekuatan mengikat umum karena telah memperoleh persetujuan dari wakil-wakilnya di parlemen.

Di Eropa Kontinental dipikirkan langkah-langkah untuk membatasi kekuasaan kekuasaan Administrasi Negara, sedangkan di negara-negara Anglo Saxon dipikirkan langkah-langkah untuk mewujudkan peradilan yang adil dan penahanan yang tidak sewenang-wenang. Selain hal yang telah dijelaskan sebelumnya, dalam Konsep Rechtsstaat terdapat pula asas-asas demokratis yang melandasinya, sebagaimana dikembangkan oleh Couwenberg, meliputi. 

a. Asas hak-hak Politik
b. Asas Mayoritas
c. Asas Pertanggungjawaban
d. Asas Perwakilan
e. Asas Publik

Keempat prinsip Negara Hukum, baik itu Rechtsstaat yang dikembangkan oleh Julius Sthal diatas, kemudian prinsip Negara Hukum Rule of law, yang dikembangkan oleh A.V. Dicey digabungkan untuk menandai ciri Negara Hukum modern dijaman sekarang. Bahkan oleh The International Commission of Jurists, prinsip-prinsip Negara Hukum itu ditambah lagi dengan Prinsip peradilan bebas dan tidak memihak (Independence and Impartiality of Judiciary) yang pada jaman sekarang makin dirasakan mutlak diperlukan dalam setiap negara demokrasi

Perkembangan Negara sangat mempengaruhi keberadaan Konstitusi sebagai Nasakah dasar atau Aturan dasar tertinggi dalam sebuah negara. Dalam sejarah perkembangan negara-negara di wilayah Barat, Konstitusi dimaksudkan untuk menentukan batas wewenang penguasa, menjamin hak rakyat, dan mengatur jalannya pemerintahan.

Kemudian, dengan kebangkitan paham kebangasaan sebagai kekuatan Pemersatu, serta dengan kelahiran Demokrasi sebagai paham politik yang progresif dan militant, konstitusi menjamin alat rakyat untuk mengatur kehidupan bersama dan untuk mencapai cita-citanya dalam bentuk negara. berkaitan dengan itu, konstitusi dijaman modern tidak hanya memuat aturan-aturan hukum, tetapi juga merumuskan atau menyimpulkan prinsip-prinsip hukum, haluan negara, dan patokan kebijaksanaan, yang kesemuanya mengikat penguasa. 
Janedjri M. Gaffar mengemukakan bahwa apabila demokrasi dan nomokrasi dianut bersama-sama dalam suatu negara, keduanya akan melahirkan konsep negara hukum yang demokratis. Dari sisi pemahaman kedaulatan rakyat, kekuasaan tertinggi dalam suatu negara berada ditangan rakyat. Kekuasaan tertinggi ditangan rakyat itu dibatasi oleh kesepakatan yang mereka tentukan sendiri secara bersama-sama, yang dituangkan dalam aturan hukum, yang berpuncak pada rumusan Konstitusi, sebagai produk kesepakatan tertinggi dari seluruh rakyat.156Sebagai produk kesepakatan, maka Konstitusi juga dapat diubah.

Menurut Mahfud MD, ini wajar saja sebab konstitusi adalah kesepakatan politik yang harus ditetapkan dari berbagai pilihan yang berdasar perspektifnya sendiri samasama baik dan rasional.157 Harus diingat bahwa tidak ada di dunia ini Konstitusi yang sempurna dan dapat disetujui selruh isinya oleh semua orang. Di dalam negara demokrasi, perbedaan dan kontroversi adalah keniscayaan, sekurang-kurangnya hampir dapat dipastikan adanya pandangan yang berbeda, namun memang dari perbedaanperbedaan itulah Demokrasi menjadi penyaring untuk mencapai resultante mealui prosedur hukum yang sah.

Sebuah negara yang menganut Paham demokrasi, maka konsekuensi yang harus lahir dalam konstitusinya pun harus menuangkan atau mencirikan paham demokrasi tersebut. Sebagaimana dijelaskan sebelumnya bahwa pada dasarnya konstitusi merupakan Resultante (Kesepakatan) antara rakyat dengan para penguasa di dalam negara, dengan demikian telah jelas bahwa kesepakatan yang dari rakyat kepada pemerintah haruslah memuat aspirasi dari rakyat itu sendiri. Konstitusi dapatlah dikatakan juga sebagai Produk politik, sebab dari kesepakatan antara rakyat dengan pemerintah tersebut, maka dituangkanlah suara kesepakatan itu didalam suatu naskah yang menjadi dasar dan tonggak berdirinya Hukum dalam sebuah Negara. Selain itu, jika 
dikaji dari ajaran Hans Kelsen maka Konstitusi merupakan Norma dasar Negara (Staatfundamental noorm).

\section{PENUTUP}

Ilmu negara dapat dikatakan sebagai landasan atau dasar untuk mempelajari hukum negara. Tanpa pemahaman tentang hakikat, bentuk, dan asal mula negara dalam pengertian universalnya, orang-orang akan kesulitan untuk memahami hukum negara. Ilmu tersebut akan membantu mereka memahami pengertian pokok dan asas-asas pokok tentang negara secara umum. Ilmu negara mampu memberi dasar teori bagi hukum tata negara yang sifatnya positif.

Hukum negara dapat dikatakan sebagai penyelarasan atau penerapan nyata dari teori-teori yang dipelajari dari ilmu negara. Sehingga, dapat disimpulkan bahwa hukum a negara adalah sebuah ilmu pengetahuan praktis dan ilmu negara adalah sebuah ilmu pengetahuan murni. Sebagai sebuah ilmu pengetahuan praktis atau applied science, hukum negara mempelajari hal-hal yang disediakan, diselidiki, dan dikumpulkan oleh ilmu negara sebagai ilmu pengetahuan murni.

Konsep Negara Hukum adalah negara yang berdiri di atas hukum yang menjamin keadilan kepada warga negaranya. Keadilan merupakan syarat bagi tercapainya kebahagian hidup untuk warga negaranya, dan sebagai dasar dari pada keadilan itu perlu diajarkan rasa susila kepada setiap manusia agar ia menjadi warga negara yang baik. Demokrasi sebagai dasar hidup bernegara memberi pengertian bahwa pada tingkat terakhir rakyat memberikan ketentuan masalah pokok yang mengenai kehidupannya, termasuk dalam menilai kebijaksanaan negara, oleh karena itu kebijaksanaan tersebut menentukan kehidupan rakyat. 
Negara yang menganut Paham demokrasi, maka konsekuensi yang harus lahir dalam konstitusinya pun harus menuangkan atau mencirikan paham demokrasi tersebut. Sebagaimana dijelaskan sebelumnya bahwa pada dasarnya konstitusi merupakan Kesepakatan antara rakyat dengan para penguasa di dalam negara, dengan demikian telah jelas bahwa kesepakatan yang dari rakyat kepada pemerintah haruslah memuat aspirasi dari rakyat itu sendiri. Konstitusi dapatlah dikatakan juga sebagai Produk politik, sebab dari kesepakatan antara rakyat dengan pemerintah tersebut, maka dituangkanlah suara kesepakatan itu didalam suatu naskah yang menjadi dasar dan tonggak berdirinya Hukum dalam sebuah Negara.

\section{DAFTAR PUSTAKA}

Darmini Roza dan Laurensius Arliman S, Peran Pemerintah Daerah Di Dalam Melindungi Hak Anak Di Indonesia, Masalah-Masalah Hukum, Volume 47, Nomor 1, 2018. https://doi.org/10.14710/mmh.47.1.2018.10-21

Laurensius Arliman S, Peranan Metodologi Penelitian Hukum di Dalam Perkembangan Ilmu Hukum di Indonesia, Soumatera Law Review, Volume 1, Nomor 1, 201. http://doi.org/10.22216/soumlaw.v1i1.3346.

Laurensius Arliman S, Peran Badan Permusyawaratan Desa di Dalam Pembangunan Desa dan Pengawasan Keuangan Desa, Padjadjaran Journal of Law, Volume 4, Nomor 3, 2017. https://doi.org/10.15408/jch.v4i2.3433.

Laurensius Arliman S, Penanaman Modal Asing Di Sumatera Barat Berdasarkan Undang- Undang Nomor 25 Tahun 2007 Tentang Penanaman Modal, Supremasi Hukum, Volume 1, Nomor 1, 2018. http://dx.doi.org/10.36441/hukum.v1i01.102 .

Laurensius Arliman S, Memperkuat Kearifan Lokal Untuk Menangkal Intoleransi Umat Beragama Di Indonesia, Ensiklopedia of Journal, Volume 1, Nomor 1, 2018, https://doi.org/10.33559/eoj.v1i1.18.

Laurensius Arliman S, Perkawinan Antar Negara Di Indonesia Berdasarkan Hukum Perdata Internasional, Kertha Patrika, Volume 39, Nomor 3, 2017, https://doi.org/10.24843/KP.2017.v39.i03.p03.

Laurensius Arliman S, Partisipasi Masyarakat Di Dalam Pengelolaan Uang Desa Pasca UndangUndang Nomor 6 Tahun 2014 Tentang Desa, Jurnal Arena Hukum, Volume 12, Nomor 2, 2019, https://doi.org/10.21776/ub.arenahukum.2019.01202.5. 
Laurensius Arliman S, Mewujudkan Penegakan Hukum Yang Baik Di Negara Hukum Indonesia, Dialogica Jurnalica, Volume 11, Nomor 1, 2019, https://doi.org/10.28932/di.v11i1.1831.

Laurensius Arliman S, Mediasi Melalui Pendekatan Mufakat Sebagai Lembaga Alternatif Penyelesaian Sengketa Untuk Mendukung Pembangunan Ekonomi Nasional, UIR Law Review, Volume 2, Nomor 2, 2018, https://doi.org/10.25299/uirlrev.2018.vol2(02).1587

Laurensius Arliman S, Peranan Filsafat Hukum Dalam Perlindungan Hak Anak Yang Berkelanjutan Sebagai Bagian Dari Hak Asasi Manusia, Doctrinal, Volume 1, Nomor 2,2016.

Laurensius Arliman S, Ni Putu Eka Dewi, Protection of Children and Women's Rights in Indonesia through International Regulation Ratification, Journal of Innovation, Creativity and Change Volume 15, Nomor 6, 2021.

Laurensius Arliman S, Gagalnya Perlindungan Anak Sebagai Salah Satu Bagian Dari Hak Asasi Manusia Oleh Orang Tua Ditinjau Dari Mazhab Utilitarianisme, Jurnal Yuridis, Volume 3, Nomor 2, 2016, http://dx.doi.org/10.35586/.v3i2.180.

Laurensius Arliman S, Tantangan Pendidikan Kewarganegaraan Pada Revolusi 4.0, Jurnal Ensiklopedia Sosial Review, Volume 2, Nomor 3, 2020. 